\title{
Accession of Scholarly Electronic Information Resources for Libraries: Issues and Opportunities
}

\author{
Kavita Biradar ${ }^{1}$, Geeta Kittur ${ }^{2}$ \\ ${ }^{1}$ Research Scholar, Department of Library and Information Science, Bangalore University, Bangalore-560056 \\ ${ }^{2}$ Chief Librarian, Dharwad Advocates Bar Association, Dharwad- 580001
}

\begin{abstract}
The study indent to identify various modes of accessing electronic information resources such as journals website, publishers' portals, aggregators' portals, library consortia, library networks, institutional repositories, academic social m edia and cloud storage. The study also discuss some of mode of accessing electronic information resources including current access, back volume access, perpetual access, abstract only access open access and other. The study discussed some issues facing by especially Indian libraries and possible suggestion as made to improvement of library service and resource in terms of electronic information resources.
\end{abstract}

Keywords: electronic information resources, accession of e-resources, scholarly e-resources

\section{Introduction}

Evolution and growth of e-publishing industry in the field of ICT has given birth to electronic resources. It is an umbrella term for all digital resources. They refer to the use of information technology in the production of publication and the electronic distribution of text through computer terminals. These resources play an important role in the creation, transmission and storage of information. Electronic resources encompass many genre, formats, storage, and delivery mediums. It is a combinationof those resources that

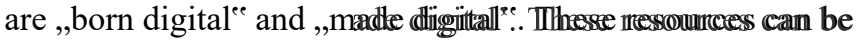
stored and delivered through CD-ROM, a magnetic tape or a server that is accessed through the Internet (Johnson, 2004). Thus electronic information arena involves resources covering a wide variety of materials, including indexing and abstracting services,electronic books and serials, electronic databases offered by information aggregators, document delivery services and web sites. Many of these resources may be locally mounted om a libnanyy's server or theyy maay bee accessed remotely by modem or through direct Internet connections maintained by the library. The importance of electronic information resources in academic institutions is ever growing. Their primary motto is to provide access rather than ownership.

\section{Development of E-Resources}

Earlier, information resources are available for kings, royal family, scholars and nobles. However after invent of printing press, dissemination of information resources became wide spread. Royal Societies, Non-Profit Making organisations started publishing information resources in print format to reach out its users all around the world. The users of these information resources were scattered over the vast area, it was not possible to reach out every user speedily and timely. If the research out puts are not able to reach out in time, than there is no more value for such kind of research. Meanwhile in the beginning of 1990s the advent of internet makes possible dissemination of these resources timely. The information resources are available on internet are called electronic information resources. Internet technology made electronic information resources publishing more easily than ever before. The ICT facilitate the publishers to publish more and more journals and other electronic information resources, through that they can get huge profit. SHERPA/RoMEO project listed 23,000+ open

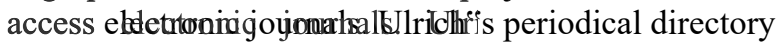
listed out $300,000+$ periodicals publishing in different languages in different disciplines from all over the world.

\section{Role of E-Resources in Learning and Teaching}

Information Communication Technology made easy to access the electronic information resources. Due to advent of ICT it became possible to use electronic information resources in teaching and learning by teachers and studentsefficiently. It is easier for teachers and students to access from home itself and by using mobile technology also we can access the electronic information resources easily. This makes teaching and learning more effective. A teacher can access the recent research output easily, through that teacher can update and make teaching effectively. On the other hand it is possible students to prepare for exams and writing assignments without difficulty due to access of electronic informattiom nesuncess. For example courseware ${ }^{\text {ee }} \mathrm{s}$ available in electronic format, which can access by any students from any country. Such a courseware ${ }^{\text {ec }}$ are includes E-PG-Pathashala, e-Gynakosh, MIT courseware ${ }^{e e}$.

\section{Accessing Mode of E-Resources}

Some of modes of accessing electronic information resources are discussed below.

\subsection{Current Access}

Current accesses of information are usually more costly than any other type of electronic information resources. Usually current access consists of current year access of information resources but some extent previous years contents also included in current access. Most of the libraries and readers are used the current journals, in current access every year users has to subscribe to the electronic information resources. Current accessing resources are consists recent 


\section{International Journal of Science and Research (IJSR) \\ ISSN (Online): 2319-7064}

Index Copernicus Value (2015): 78.96 | Impact Factor (2015): 6.391

research trends and outputs by scholars in different disciplines.

\subsection{Retrospective Access}

Retrospective access also called back volumes access. Publishers are publishing different electronic information resources under single platform called databases. Most of the time retrospective accesses of electronic information resources are provided with current access but the user has to pay extra payment. Sometime users needed the retrospective electronic information resources along with current access. Retrospective accesses are not more costly as compare to current access retrospective access are more important in strengthening collection of any library.

\subsection{Perpetual Access}

Perpetual access is getting permanent rights to access the electronic information resources to on-going access in the library. Libraries are retaining the electronic information resources after contractual agreement between publishers and libraries to these materials. Once you agreed for perpetual access no need to pay for again in future. However it is need to pay for current accession of any electronic information resources. In case publications is ceased in future, publishers has to provide full text articles and resources permanently in CD ROM or else pass the resources to some other publishers through that libraries can access electronic information resources without any hurdles.

\subsection{Partial Access}

Standalone journals are usually not providing partial access to information resources. However, most popular publishers provide partial access to the electronic information resources, if the database is subscribed. Partial access provide a few years usually, back volumes, journals access to the subscribers. Sometime few current articles are given access to the subscribers.

\subsection{Abstract Only}

Most journals and publishers of electronic information resources are providing abstract only. Many of the indexing and abstracting databases are providing such kind of services. Some publishers provide abstract and citations on paid basis like SCOPUS and Thomson Reuters etc. some of publishers provide free access like LISTA, Google Scholar, Agricola, ERIC, etc.

\subsection{Content Bundle Access}

Reputed publishers like Elsevier, Emerald Insight, John Wiley, Taylor and Francis, Springer, Sage are providing contents in bundle access in different disciplines. Every field of research there is a few journals are most popular and used by more users. Usually such kinds of journals have high cost. It is possible to subscribe a few high priced journals only. Sometime publishers offers „Bundle Access, ${ }^{e ~ i t ~}$ consists core journals as well as other related journals in any particular subject. For example STM-Science, Technology and Medical Science, HSS- Humanities and Social Sciences, ECM- Economics Commerce and Management.

\subsection{Open Access}

Many of standalone journals and other electronic information resources providing open access. Many of the publishers also provide few journals and contents providing open access. Many journals directories like DOAJ provides $10000+$ journals, OpenJGate- $4000+$ journals can be accessed openly. Open access journals providing access to their contents without any legal, financial and technical barrier. Open access resources can be access by anybody from any corner of the world without any restriction from anybody. These are available free of cost to all.

\section{Accession Platforms of E-Resource}

Some of the platforms for accessing electronic information resources are discussed below.

\subsection{Journals Website}

Many of the journals and other electronic information resources are publishing stand alone. Such resources are available through their own websites. Associations, Organisations, Institutions, Universities and research councils are providing such a kind of electronic information resources to user community. Journals, Reports, Standards, Books are some examples for standalone electronic information resources available through website. DESIDOC journal of Library and information technology is an example for a journal.

\subsection{Publishers Portals}

Different electronic information resources like books, journals, reports, case studies book reviews and other useful information can be accessed through reputed publisherse portals. Usually they provide number of journals, books, and other information resources in a single platform through databases. Many reputed publishers like Science Direct, Springer, Sage, Emerald Insight, Taylor and Francis, Black Well, John Wiley are providing access to number of electronic information resources through their web portals. Libraries are accessing more number of journals from publisherse web portals all over the world through subscribing every year.

\subsection{Aggregators databases}

Aggregators provide access to different materials from different publishers. Aggregators are neither the author of resources nor publishers of information resources. However they are facilitators of information resources consolidating from different publishers. Aggregators usually not provide current access to information resources. Some time they provide current access but they have certain embargo period, usually from six months to two years. Aggregators are providing single platform to access different electronic information resources from different publishers. JSTOR, EBSCO, ABI Inform are most popular aggregators. 


\section{International Journal of Science and Research (IJSR) \\ ISSN (Online): 2319-7064}

Index Copernicus Value (2015): 78.96 | Impact Factor (2015): 6.391

\subsection{Cloud Storage}

The publishers, authors, Institutions are came in a collaborative efforts to store their information resources and access the stored information whenever they needed. It is a group effort to sharing the information resources between them.

\subsection{Academic Social Media}

The advent of web 2.0 technology enabled emergence of social networking sites. Social media are helped people to stay connected and academic social media help to share their research papers to the academic communities. Usually individuals involved development of academic social media platform to share, disseminate and accessing academic information resources. Research Gate, Adcademia.edu, slide share, Mendeley and other academic social media are being used.

\subsection{Library Consortium}

The increase of sales of titles in bundles has been paralleled by the increasing importance of sales of such bundles to library consortia (though it is important to recognise the two different concepts - some publishers deal with consortia but do not offer bundled content). Consortia arose in order to provide efficiencies by centralising services (catalogues, resources, Interlibrary Loan, shared library management systems, etc.) and centralising purchasing, to increase the purchasing power of libraries in negotiation with publishers, and increasingly to take advantage of bundled electronic content. The numbers of consortia have been growing strongly: the Ringgold Consortia Directory Online lists over 400 consortia in $100+$ countries, representing over 26,500 individual libraries; of these, about 350 are responsible for licensing content. The International Coalition of Library Consortia has some 200 members.

\subsection{Library Networking}

Allen Kent has express that the success and survival of library and Information Centres will depend on how much and what extent libraries cooperate with each other in future. The increasing costs of information source materials, increasing cost of processing documents and their information contents, decreasing budgets and wide use of micro and mini computers have contributed to the development of networks. The principal motives behind networking are maximizing the utilization of existing information resources by sharing and providing speedy access to information resources located at different places through communication channels.

\subsection{Institutional Repositories}

Institutional repositories are increasing rapidly on these days. Institutional repositories consist of intellectual out puts of parent organisation. The faculty members and researchers are contributing their work to the Institutional repositories. Repositories consists of research papers including pre prints, post prints, monograph, conference papers, working papers, reports, annual reports, etc. Institutional repositories can be accessed by organisation members and other research communities.

\section{Issues in Accessing Resources}

\subsection{Serial Crisis}

The sudden price hike in information resource are called serial crisis. Most of the libraries all around the world facing cost cutting in library budget, on the other hand currency fluctuation is decreasing the value of domestic currency on the contrast prices of electronic information resources are increasing more than whole sale price index. This leads to less subscription of electronic information resources in more prices and providing fewer resources to the more users. It is become common phenomena in every library all over the world.

\subsection{Predatory Journals}

Predatory journals are become so proactive in publishing industry. Predatory journals are not providing peer review referred article. They charge APC (Article Processing Charge) to authors. They publish for only APC not really varied about research contents. So accessing such electronic resources will not satisfy the users. Even they try to force the libraries to subscribe such electronic information resources this is greater issue in open access scholarly communication and publishing.

\subsection{Lack of ICT Infrastructure}

Being a developing country India is still struggling provide basic ICT infrastructure to the university libraries and colleges libraries. College libraries are facing worse conditions in terms of ICT Infrastructure. If the authorities are provide good ICT infrastructure, than only it is possible to access to the good number of electronic information resources. The ICT infrastructure also facilitates that to make use of accessed resources by more number of users. Without having good ICT infrastructure, it is not so easy to subscribe and use the resources by users.

\subsection{Archival Issues}

One of the most controversial issues used to inflate the discussion of archival records are litigations. Copy rights are another major issue exposed by library and information centres while archiving records. Many a timees publishers not allow the authors to deposit their research papers in institutional repositories. Some cases publishers allow the pre prints but not post prints of research articles. For archiving the materials there need of good information technology infrastructure facility and skilled library staff. Copy rights protected under intellectual property rights are not able to archive in institutional repositories.

\subsection{Management Issues}

Libraries policies for accessing information resources by users may be generallycategorised as open access or closed access. Maintaining open access system within the campus to users will be the greater help to users, because, many 


\section{International Journal of Science and Research (IJSR) \\ ISSN (Online): 2319-7064}

Index Copernicus Value (2015): 78.96 | Impact Factor (2015): 6.391

users do not well worse in access electronic information resources.

\subsection{Accessing Control}

In traditional subscription system print resources are purchased are become permanent resources of any library. However in electronic environment the electronic information resources are subscribed are only accessible for that particular library. For the same issues library need to pay next year and upcoming years as well. Libraries do not have control over electronic information resources. Hence library facing access control issue in electronic information resources. It has to solve by publishers and library associations and institutions.

\subsection{Low bandwidth Access}

India is still facing the low bandwidth connectivity in almost all institutions. Many educational institutions like colleges and schools not connected with internet access. In this case it is not possible to access the electronic information resources. Many Indian Universities are still facing low bandwidth connectivity. We are still in fourth generation access to the internet. However many developed countries are going beyond sixth generation of internet. Low internet bandwidth cause low accessing rate and time consuming process.

\section{Suggestions and Conclusion}

Serial crisis is an unavoidable phenomenon for libraries However, a library has to support for open access scholarly communication in order to overcome from serial crisis. The open access journals are providing free access to all. Libraries must be aware of predatory journals. Such resources should not be subscribed. And always prefer reputed publishers for accessing electronic information resources.

While subscribing electronic information resources libraries should go for perpetual access than only it is possible libraries to retain the electronic information resources life time. Management should adopt good collection development policies as well as policies towards high usage of electronic information resources. Since, electronic information resources are costlier and available time being in current access,management policies always provide basic amenities in terms of more usage of electronic information resources. Libraries should develop good information communication technology infrastructure in order to access disseminate the electronic information resources most speedy and timely.

Good ICT infrastructure helps the libraries in archiving institutional publications encouraging the archival is enhance the usage of electronic information resources. For archiving library should have better archiving software, digitisation machineries helps for good archival collection development. Management also consider providing good bandwidth access of internet. Electronic information resources are emerging day by day and near future is paperless society therefore libraries should ready for it well in advance in order to keep providing good services to the library users.

\section{References}

[1] Armstrong, E. A., Lener, E. F., Kok, V. T., \& Croft, V. $\mathrm{F}$, Electronic Resources Access: issues and resolutions in two academic libraries.Proceedings of the 4th International Conference of Animal Health Information Specialists, Budapest, Hungary, 6-9 August (2003).

[2] Byrum Jr, J. D. (2001). Challenges of Electronic Resources: State of the Art and Unresolved Issues [English version presented at the International Conference $]=$ Le sfide delle risorse elettroniche: stato dellearte e problemi irrisolti [Versione italiana presentata alla Conferenza internazionale].

[3] Chandel, A. S., \& Saikia, M. (2012). Challenges and opportunities of e-resources. Annals of Library and Information Studies (ALIS), 59(3), 148-154.

[4] Chapin, B. (1999). Access to electronic information, services, and networks: An interpretation of the library Bill of Rights. Teacher Librarian, 26(5), 21.

[5] Johnson, Peggy, Fundamentals of Collection Development and Management,Chicago: American Library Association, (2004).

[6] Johnson, S., Evensen, O. G., Gelfand, J., Lammers, G., Sipe, L., \& Zilper, N. Key issues for e-resource collection development: a guide for libraries, Acquisition andCollection Development Section , IFLA,January, (2012).

[7] Kaur, N, E-Resources and collection development: Emerging issues for the Academic Libraries, 5th International CALIBER -2007, Panjab University, Chandigarh, 08-10 February, (2007).

[8] Kent, Allen, "Library Resource Sharing Networks: How to Make a Choice", Library Acquisitions: Practice and Theory, 2(2),(1978), pp. 69-76.

[9] Smart, P, The big picture: scholarly publishing trends 2014. Science Editing, 1(2), (2014), 52-57.

[10] Ugwu, C. I., \& Onyegiri, D, C, Management problems of electronic information resources: A case study of UNN Library. International Journal of Library and Information Science, 5(5), (2013), 126-133.

[11] Venkatachalam, A. M, Resource sharing among management institute libraries in Tamilnadu: a study, PhD thesis, Alagappa University, 2011.

[12] Ware, M., \& Mabe, M, The STM report: An overview of scientific and scholarly journal publishing,(2015).

[13] White, G. W., \& Crawford, G. A, Developing an electronic information resources collection development policy. Asian Libraries, (2013). 